from the fact that in the Biochemische Zeitschrift alone she had to deal with 268 volumes. A letter of appreciation of this work from the members of the staff of the Sub-Department of Plant Physiology gave her special pleasure in her last illness. Concurrently with the work on the index, she found scope for her considerable powers of draughtsmanship in making all the illustrations for a long series of papers on floral anatomy published by her friend Miss E. R. Saunders, between the years 1923 and 1936.

Over a very long period-indeed until the failure of her health brought all activities to a close-Dora Pertz was content to give her time with complete steadiness and regularity to indexing and drawing, though these somewhat mechanical occupations could not, in the nature of things, have for her the compelling charm of her own chosen work. In her absence of personal ambition, and the disinterestedness of her desire to be serviceable to botany, Dora Pertz was true to the family tradition handed on to her by Horner, Lyell and Bunbury; she was one with them in pursuing science simply for the love of it, and in being -in the basic sense of that much mishandled word-an amateur. AGNes ArBer.

\section{Dr. Moses Gaster}

WE regret to record the death of Dr. Moses Gaster, the distinguished Jewish scholar, historian, and folklorist, formerly Chief Rabbi, which took place suddenly on March 5 at the age of eighty-two years.

Moses Gaster was born in Bucharest on September 16, 1856. He was the son of the Chevalier A. E. Gaster, and a member of a family which for long had been settled in Rumania. He graduated at the University of Bucharest and received the degree of Ph.D. from the University of Leipzig and the rabbinical diploma from the Jewish Rabbinical Seminary at Breslau. On his return to Bucharest in 1880 , after a period of literary activity, he became lecturer on Rumanian language and literature at the University of Bucharest and inspector-general of schools, holding in addition other public offices; but his activities in connexion with the settlement of Jews in Palestine led to his inclusion among the Jews expelled from Rumania at this time at the instance of Russia. Dr. Gastier then settled in England, where his work as Ilchester lecturer in Greco-Slavonic languages in the University of Oxford rapidly secured him a place in the front ranks of scholarship.

Dr. Gaster was the author of a large number of works on Jewish historical subjects, as well as in the more advanced Hebrew and Rabbinical studies. As a folklorist he inevitably came to be regarded as the first authority in Great Britain on the folk-lore of Rumania ; but his interest in folk-lore studies was by no means confined to either his country of origin or to his special field of Jewish scholarship. His wise counsel and ready ability in suggestion were ever at the service of his fellow workers. Among his publications may be mentioned as of special interest to students of folk-lore and comparative religion "Rumanian Bird and Beast Stories", "Studies and
Texts in Folklore, Magic, Medieval Romance, Hebrew Apocrypha, and Samaritan. Archæology", "The Samaritans", embodying the Schweich Lectures of 1925, and "The Sword of Moses" an early Jewish magical work which had been lost for a thousand years until discovered and published by him.

On the cancellation of his order of expulsion Dr. Gaster paid several visits to Rumania and for a report on the English educational system, published as a Rumanian State paper, and other services he received the Rumanian Order of Merit of the First Class.

\section{Dr. Antoine Béclère}

Dr. Antorne Louis Gustave Béclere, the pioneer of medical radiology in France, died at the age of eighty-two years on February 24 in Paris, where he was born on March 17, 1856, the son of a general practitioner, and received his medical education.

Béclère qualified in 1882 with a thesis on the contagion of measles and at first took a keen interest in other infectious diseases, especially smallpox-for which in collaboration with Chambon and Ménard he introduced treatment by convalescent serumvaccinia and syphilis. Shortly after the discovery of $\mathrm{X}$-rays in 1895 he became engrossed in the study of radiodiagnosis and radiotherapy, and at his own expense fitted up a radiological laboratory at the Hôpital Tenon in 1898 and started a course of free instruction in medical radiology which he resumed in 1899 after his transfer to the Hôpital Saint Antoine and continued until his retirement in 1921.

During the Great War, Béclère was director of a radiological centre at the Val de Grâce military hospital. In addition to numerous communications to medical societies and journals, he was the author of works on "Röntgen Rays in the Diagnosis of Tuberculosis" (1899), "Röntgen Rays in the Diagnosis of Non-Tuberculous Diseases of the Chest", several articles in the treatise of medical radiology edited by Prof. Bouchard (1904), and "Röntgen Rays in the Diagnosis of Internal Diseases" (1904).

Besides being Commander of the Legion of Honour, Béclère received many well-merited distinctions. In 1928 he was elected president of the Académie de Médécine, of which he had been made a member in 1908. He was also one of the first members of the recently resuscitated Académie de Chirurgie. In 1931 he was president of the third International Congress of Radiology held in Paris, and the same year he was elected an honorary fellow of the Royal Society of Medicine. On attaining his eightieth birthday in 1936 his pupils, colleagues and friends dedicated to him a jubilee volume in which his contributions not only to radiology but also to pædiatrics, experimental medicine, neurology, endocrinology, diseases of the chest, diseases of the abdomen and gynæcology formed the subjects of appreciation by well-known specialists. The journal Strahlentherapie also devoted a Festschrift to him on the same occasion. During the last years of his life, he resumed his study of vaccinia and syphilis.

J. D. Rolleston. 